\title{
Low Incidence of Opioid-Induced Respiratory Depression Observed with Oliceridine Regardless of Age or Body Mass Index: Exploratory Analysis from a Phase 3 Open-Label Trial in Postsurgical Pain
}

\author{
Marek Brzezinski · Gregory B. Hammer • Keith A. Candiotti • \\ Sergio D. Bergese · Peter H. Pan • Michael H. Bourne • \\ Cathy Michalsky · Linda Wase · Mark A. Demitrack · Ashraf S. Habib
}

Received: November 4, 2020 / Accepted: December 22, 2020 / Published online: January 21, 2021

(C) The Author(s) 2021

\section{ABSTRACT}

Introduction: Advanced age and obesity are reported to increase the risk of opioid-induced respiratory depression (OIRD). Oliceridine, an

Supplementary Information The online version contains supplementary material available at https:// doi.org/10.1007/s40122-020-00232-X.

M. Brzezinski $(\square)$

VA Medical Center, University of California San Francisco, San Francisco, CA, USA

e-mail: marek.brzezinski@ucsf.edu

G. B. Hammer

Stanford University School of Medicine, Stanford, CA, USA

K. A. Candiotti

Department of Anesthesiology, University of

Miami/Jackson Health System, Miami, FL, USA

\section{S. D. Bergese}

School of Medicine, Stony Brook University, Stony Brook, NY, USA

P. H. Pan

Wake Forest School of Medicine, Winston-Salem,

NC, USA

M. H. Bourne

Salt Lake Orthopaedic Clinic, St. Marks Hospital, Utah, USA

C. Michalsky · L. Wase · M. A. Demitrack

Trevena, Inc., Chesterbrook, PA, USA

A. S. Habib

Duke University Medical Center, Durham, NC, USA intravenous opioid, is a G-protein-biased agonist at the $\mu$-opioid receptor that may provide improved safety. The recent phase 3 ATHENA open-label, multicenter study evaluated postoperative use of oliceridine in patients with moderate-to-severe acute pain. This exploratory analysis of the ATHENA data examined the incidence of OIRD in older ( $\geq 65$ years) and/or obese (BMI $\geq 30 \mathrm{~kg} / \mathrm{m}^{2}$ ) patients and analyzed risk factors of OIRD.

Methods: Patients aged $\geq 18$ years with a score $\geq 4$ on an 11-point numeric pain rating scale (NPRS) received IV oliceridine as needed via bolus dosing and/or patient-controlled analgesia (PCA). OIRD occurring within $48 \mathrm{~h}$ of last dose of oliceridine was defined using two established definitions: (1) naloxone use, (2) respiratory rate $<10$ breaths per minute and/or oxygen saturation $<90 \%$.

Results: A total of 724 surgical patients with a mean age of $54.5 \pm 15.9$ years and a mean NRS score of $6.2 \pm 2.1$ were included in this analysis; $33.3 \%(241 / 724)$ were $\geq 65$ years of age and $46.3 \%(335 / 724)$ had BMI (body mass index) $\geq 30 \mathrm{~kg} / \mathrm{m}^{2}$. The overall OIRD incidence was $13.7 \%$ with no patients requiring naloxone. The OIRD incidence was similar in the elderly and younger adults' cohorts [ 10.8 vs. $15.1 \%$, OR $0.68(0.42,1.1), p=0.11]$, and in obese and non-obese groups [14.0 vs. $13.4 \%$, OR 1.06 $(0.69,1.62), p=0.80]$. In patients that were both elderly and obese $(n=120)$, the incidence was $10.8 \%$. The multivariate analysis identified 
baseline NRS $\geq 6$ [OR $1.6(1.0,2.4), p=0.0499]$, PCA administration [OR $1.9 \quad(1.2,3.1)$, $p=0.005]$, and concomitant use of benzodiazepines and/or gabapentinoids [OR 1.6 (1.0, $2.6), p=0.045]$, as being associated with OIRD. Conclusions: Postoperative oliceridine use in patients with advanced age and/or increased BMI was not associated with increased risk of OIRD.

Keywords: Analgesia; Biased opioid; Oliceridine; Postoperative pain; Respiratory depression

\section{Key Summary Points}

\section{Why carry out this study?}

Advanced age and obesity are known risk factors for the development of opioidinduced respiratory depression (OIRD).

In this exploratory retrospective analysis from the open-label ATHENA study, we tested the hypothesis that the use of oliceridine, a selective G-protein $\mu$ agonist, in at-risk surgical populations, defined as (1) elderly ( $\geq 65$ years), (2) obese (BMI $\geq 30 \mathrm{~kg} / \mathrm{m}^{2}$ ), and, (3) elderly and obese patients was not associated with increased incidence of OIRD.

\section{What was learned from the study?}

Postoperative oliceridine use in patients with advanced age, increased BMI, or in elderly with increased BMI was not associated with increased risk of OIRD.

\section{DIGITAL FEATURES}

This article is published with digital features, including a summary slide, to facilitate understanding of the article. To view digital features for this article go to https://doi.org/10.6084/ m9.figshare.13469484.

\section{INTRODUCTION}

Optimal analgesic management, an essential component of postoperative care, has been reported to reduce postoperative complications, as well as improve recovery and patient satisfaction $[1,2]$. Pain management with conventional opioids, representing the principal component of most pain management plans, can, however, be challenging due to dose-limiting opioid-related adverse events [3]. In particular, opioid-induced respiratory depression (OIRD), a potentially fatal complication in the acute setting, represents a major limitation to the effective use of opioids [4-6]. The reported incidence of OIRD varies depending on the study design and definitions used, ranging from 0.04 to $0.5 \%$ when the administration of naloxone is used to define OIRD, to as high as $23-41 \%$ when assessed by bradypnea or hypoxemia [7-9]. Patients considered to be at high risk for the development of OIRD include the elderly, patients with a high body mass index (BMI), patients with increased comorbidity burden, and those receiving concomitant sedatives $[8,10,11]$. However, data in these populations are limited to observations from case reports and observational studies as typically they are excluded from controlled clinical trials $[12,13]$.

To minimize the use of opioids, a joint task force of the American Pain Society and American Academy of Pain Medicine put forth guidelines focusing on the judicious use of opioids by introducing multimodal analgesia $[2,14]$. In recent years, with the introduction of enhanced recovery after surgery (ERAS) protocols, a variety of multimodal analgesic pathways based on opioid-free analgesia in the postoperative period have been developed $[15,16]$. However, the use of nonopioid multimodal analgesics used in ERAS pathways has not consistently shown a benefit for the relevant reduction of pain or opioid use $[16,17]$. Indeed, the Center of Disease Control and Prevention suggests that in acute postsurgical pain, the benefits of a limited course of opioids may outweigh the risks if pain management is inadequate with nonopioid therapies [18]. 
Given the aging surgical population [19], the increasing prevalence of obesity influencing surgical outcomes [20], combined with a lack of proven multimodal nonopioid analgesic pathways, there is a real and urgent clinical need for opioids with an improved safety profile in highrisk patient populations.

Conventional opioids that bind to the $\mu$ opioid receptor activate two distinct pathways: G-protein, resulting in analgesic effect, and $\beta$ arrestin, associated with opioid-related adverse events, including OIRD [21-24]. Selective (biased) opioid-receptor agonists may offer a better safety profile while providing adequate analgesia. Oliceridine (TRV130; Trevena Inc., Chesterbrook, PA, USA) represents a new firstin-class intravenous (IV) $\mu$-opioid receptor agonist that is G-protein-biased, with substantially reduced recruitment of the $\beta$-arrestin pathway [24-27]. The recent phase 3, open-label, singlearm, multicenter trial (ATHENA, NCT02656875) in patients undergoing a wide range of surgeries ("real-world setting") provided support that postoperative IV oliceridine administered alone or as a component of multimodal analgesia is generally safe and welltolerated in patients experiencing moderate-tosevere acute pain [28].

The purpose of the current analysis was to examine the incidence of OIRD among elderly ( $\geq 65$ years) and/or obese $\left(\mathrm{BMI} \geq 30 \mathrm{~kg} / \mathrm{m}^{2}\right.$ ) surgical subjects in the ATHENA trial. We hypothesized that the use of oliceridine in atrisk surgical populations, defined as (1) elderly ( $\geq 65$ years), (2) obese (BMI $\geq 30 \mathrm{~kg} / \mathrm{m}^{2}$ ), and, (3) elderly and obese patients, was not associated with an increased incidence of OIRD. A second objective was to examine the association between other known risk factors and the occurrence of OIRD.

\section{METHODS}

The ATHENA trial was an open-label trial conducted in compliance with the protocol and regulatory requirements consistent with the International Council on Harmonization Good Clinical Practice Guidelines and the ethical principles of Declaration of Helsinki [28]. The trial protocol was approved by the institutional review board at each investigational site and all patients provided written informed consent before any study procedures were performed [28].

The study design and the results for the ATHENA trial have been reported in detail elsewhere [28]. Briefly, the ATHENA study enrolled patients 18 years of age or older, experiencing moderate-to-severe acute pain following surgery or with a painful non-surgical medical condition, defined as $\geq 4$ on an 11-point numeric rating scale (NRS), [ranging from $0=$ no pain to $10=$ worst pain] $30 \mathrm{~min}$ prior to receiving the first dose of oliceridine. Subjects were treated with IV oliceridine via clinician-administered bolus dosing and/or patient-controlled analgesia (PCA) (Supplement Figure 1).

For IV bolus dosing, a loading dose of 1 to $2 \mathrm{mg}$ was administered, and a supplemental dose of $1 \mathrm{mg}$ was given within $15 \mathrm{~min}$ if needed. Subsequent doses of 1 to $3 \mathrm{mg}$ were administered every 1 to $3 \mathrm{~h}$ on as needed basis (PRN). In patients requiring rapid analgesia, loading doses of 1 to $3 \mathrm{mg}$ were administered and supplemental doses of 1 to $3 \mathrm{mg}$ every $5 \mathrm{~min}$ PRN were allowed. Subsequent doses of $1 \mathrm{mg}$ to $3 \mathrm{mg}$ every 1 to $3 \mathrm{~h}$ were used if clinically indicated. For PCA dosing, a loading dose of $1.5 \mathrm{mg}$ and demand dose of $0.5 \mathrm{mg}$ were administered using a 6-min lockout interval. If clinically indicated, $1 \mathrm{mg}$ supplemental doses were allowed PRN throughout the remainder of the treatment period.

Treatment duration for each patient was determined by the clinical need for parenteral opioid therapy. The duration of oliceridine treatment was limited to 14 days. Oliceridine was administered as part of multimodal analgesia in patients undergoing surgery with no restrictions on prior use of opioids and/or nonopioid analgesics. However, concomitant use of parenteral and/or oral opioids during treatment with oliceridine was not allowed. 


\section{Respiratory Safety}

Respiratory rate (RR) and oxygen saturation $\left(\mathrm{SpO}_{2}\right)$ were recorded during the dosing period consistent with individual patient need and based on institutional requirements.

For this exploratory analysis, two definitions of OIRD, as commonly found in the published literature, were considered: (a) naloxone use and (b) $\mathrm{RR}<10 \mathrm{bpm}$ and/or $\mathrm{SpO}_{2}<90 \%$ within $48 \mathrm{~h}$ of last dose of oliceridine [10]. However, since we have previously published that no patients in the ATHENA open-label trial required naloxone for reversal of OIRD during treatment with oliceridine [29], this exploratory analysis only included $\mathrm{RR}<10 \mathrm{bpm}$ and/or $\mathrm{SpO}_{2}<90 \%$ within $48 \mathrm{~h}$ of last dose of oliceridine.

\section{Analgesic Effectiveness}

Analgesic effectiveness was assessed as the change from baseline in the 11-point NRS pain scale. NRS pain scores were evaluated within $30 \mathrm{~min}$ before administration of the first dose of oliceridine and $30 \mathrm{~min}( \pm 10 \mathrm{~min})$ after administration of the first dose.

\section{Statistical Analysis}

For all the analyses performed, missing values for risk factors were not imputed. Descriptive statistics are displayed for the risk factors along with exposure and OIRD rates. In order to address concerns of multiplicity and limitations for being an open-label study, statistical testing was only performed in the demographics/baseline characteristics for age and BMI as well as in the logistic regression models. A $t$ test was utilized to compare demographic/baseline characteristic variables of age and BMI between the different groups.

A multivariate logistic regression model was utilized to examine the association between potential risk factors (explanatory parameters) and the occurrence of OIRD. These factors included medical comorbidities; type of surgery; concomitant use of sedatives (benzodiazepines and/or gabapentinoids); cumulative dose and total duration of oliceridine use, as well as route of delivery of oliceridine (PCA vs. IV bolus). Baseline medical comorbidity data were explored for the conditions reported to influence OIRD incidence rates [10]. The concomitant sedatives reported to be associated with increased incidence of OIRD [10] included gabapentinoids (gabapentin, pregabalin) and benzodiazepines (alprazolam, clonazepam, diazepam, lorazepam, midazolam, midazolam hydrochloride, temazepam, zolpidem, and zolpidem tartrate). Since the concomitant administration of other opioids was not allowed per the ATHENA trial protocol, opioids were not included in the analysis. Patients who received oliceridine via bolus dosing only were included in the bolus method of administration of oliceridine and those who received at least one dose via a PCA device were included in the PCA method of administration of oliceridine.

A backward elimination (or backward deletion) process was used in the regression model where all risk factors were included in the model and the variable that contributes the least to the regression model was eliminated if the factor was above the specified stay criterion of $p=0.1$. A Wald Chi-square $p$ value along with the $95 \%$ confidence interval for the odds ratio is reported for the final multivariate model. The statistical model did not include additional interaction terms to study interactions between surgical types with PCA dosing and baseline pain score to avoid quasi-complete conversion or non-convergence of the model. SAS 9.4 was utilized for this analysis. Normality was not statistically tested given the sample size and equal variance was assumed.

\section{RESULTS}

Subjects who underwent a surgical procedure in the ATHENA trial and required postoperative oliceridine administration for moderate-to-severe acute pain $(n=724)$ were included in this analysis. In these 724 subjects, the mean \pm SD age was $54.5 \pm 15.9$ years and mean \pm SD pain score was $6.2 \pm 2.1$ (NRS); $33.3 \%$ (241/724) were $\geq 65$ years of age and $46.3 \%(335 / 724)$ had a BMI of $\geq 30 \mathrm{~kg} / \mathrm{m}^{2}$. Most patients were female 
Table 1 Patient demographics and clinical characteristics by age and BMI in patients undergoing broad range of surgical procedures

\begin{tabular}{|c|c|c|c|c|c|c|c|}
\hline Characteristic & Age $<65$ years & Age $\geq 65$ years & $p$ value & $\begin{array}{l}\mathrm{BMI}<30 \mathrm{~kg} / \\
\mathrm{m}^{2}\end{array}$ & $\begin{array}{l}\mathrm{BMI} \geq 30 \mathrm{~kg} / \\
\mathrm{m}^{2}\end{array}$ & $p$ value & $\begin{array}{l}\text { Age } \geq 65 \text { years } \\
\text { with } \\
\begin{array}{l}\mathrm{BMI} \\
\mathrm{m}^{2}\end{array}\end{array}$ \\
\hline$N$ & 483 & 241 & & 389 & 335 & & 120 \\
\hline Female, $n(\%)$ & $334(69.2)$ & $136(56.4)$ & & $253(65.0)$ & $217(64.8)$ & & $72(60.0)$ \\
\hline $\begin{array}{l}\text { Age (years) } \\
\text { mean } \pm S D\end{array}$ & $46.2 \pm 2.5$ & $71.4 \pm 5.1$ & & $53.1 \pm 17.4$ & $56.2 \pm 13.8$ & 0.008 & $70.3 \pm 4.5$ \\
\hline$<65, n(\%)$ & - & - & & $268(68.9)$ & $215(64.2)$ & 0.180 & - \\
\hline$\geq 65, n(\%)$ & - & - & & $121(31.1)$ & $120(35.8)$ & & - \\
\hline \multicolumn{8}{|l|}{ Race $^{\mathrm{b}}, n(\%)$} \\
\hline White & $370(76.6)$ & $205(85.8)$ & & $305(78.8)$ & $270(80.6)$ & & $101(84.2)$ \\
\hline $\begin{array}{l}\text { African } \\
\text { American }\end{array}$ & $90(18.6)$ & $26(10.9)$ & & $64(16.5)$ & $52(15.5)$ & & $15(12.5)$ \\
\hline Other & $23(4.8)$ & $8(3.4)$ & & $18(4.7)$ & $13(3.9)$ & & $4(3.3)$ \\
\hline $\begin{array}{r}\mathrm{BMI}\left(\mathrm{kg} / \mathrm{m}^{2}\right) \\
\text { mean } \pm \mathrm{SD}\end{array}$ & $30.5 \pm 7.8$ & $30.6 \pm 6.4$ & 0.875 & $25.3 \pm 3.3$ & $36.7 \pm 5.8$ & & $35.6 \pm 4.8$ \\
\hline$<30, n(\%)$ & $268(55.5)$ & $121(50.2)$ & 0.180 & - & - & & - \\
\hline$\geq 30, n(\%)$ & $215(44.5)$ & $120(49.8)$ & & - & - & & - \\
\hline $\begin{array}{c}\text { Baseline NRS } \\
\text { pain score } \\
\text { mean } \pm S D\end{array}$ & $6.3 \pm 2.2$ & $6.0 \pm 2.1$ & & $6.2 \pm 2.0$ & $6.3 \pm 2.2$ & & $6.0 \pm 2.1$ \\
\hline
\end{tabular}

$p$ values represent comparison of the characteristics listed in column 1 between elderly vs. nonelderly; and between obese and non-obese

a Patients' self-rated pain on an 11-point NRS: $0=$ no pain to $10=$ worst pain imaginable

b Missing information in 2 patients

$(64.9 \%, 420 / 724)$ and $79.6 \%(575 / 722)$ were Caucasian. The most common surgical procedures were orthopedic $(231 / 724,31.9 \%)$, colorectal (115/724, 15.9\%), and gynecologic (115/ $724,15.9 \%)$ procedures [28]. The mean \pm SD baseline pain score for these surgical types were: $6.0 \pm 2.1$ for orthopedic surgery, $6.0 \pm 2.4$ for colorectal surgery, and $6.0 \pm 2.1$ for gynecological procedures.

\section{Patient Demographics and Clinical Characteristics of the Surgical Population}

Elderly ( $\geq 65$ years) and younger ( $<65$ years) patients: As shown in Table 1 , the mean \pm SD age in the elderly group was $71.4 \pm 5.1$ years vs. $46.2 \pm 12.5$ years in the younger adults' group. The BMI was $30.6 \pm 6.4 \mathrm{~kg} / \mathrm{m}^{2}$ in the elderly and $30.5 \pm 7.8 \mathrm{~kg} / \mathrm{m}^{2}$ in younger adults. The baseline NRS pain score was $6.0 \pm 2.1$ and $6.3 \pm 2.2$, in the elderly and younger adults, respectively. Most patients enrolled were 
Table 2 Key comorbidities in patients undergoing a broad range of surgical procedures

\begin{tabular}{|c|c|c|c|c|c|}
\hline Comorbidity & Age $<65$ years & Age $\geq 65$ years & $\begin{array}{l}\mathrm{BMI}<30 \mathrm{~kg} / \\
\mathrm{m}^{2}\end{array}$ & $\begin{array}{l}\mathrm{BMI} \geq 30 \mathrm{~kg} / \\
\mathrm{m}^{2}\end{array}$ & $\begin{array}{l}\text { Age } \geq 65 \text { years with } \\
\mathrm{BMI} \geq 30 \mathrm{~kg} / \mathrm{m}^{2}\end{array}$ \\
\hline$N$ & 483 & 241 & 389 & 335 & 120 \\
\hline COPD & $12(2.5)$ & $24(10.0)$ & $17(4.4)$ & $19(5.7)$ & $14(11.7)$ \\
\hline Sleep apnea & $52(10.8)$ & $42(17.4)$ & $25(6.4)$ & $69(20.6)$ & $29(24.2)$ \\
\hline $\begin{array}{l}\text { Cardiac } \\
\text { disease }\end{array}$ & $62(12.8)$ & $58(24.1)$ & $62(15.9)$ & $58(17.3)$ & $26(21.7)$ \\
\hline $\begin{array}{l}\text { Diabetes } \\
\text { mellitus }\end{array}$ & $55(11.4)$ & $56(23.2)$ & $42(10.8)$ & $69(20.6)$ & $26(21.7)$ \\
\hline Hypertension & $144(29.8)$ & $174(72.2)$ & $131(33.7)$ & $187(55.8)$ & $97(80.8)$ \\
\hline
\end{tabular}

All data presented as $n$ (\%), COPD chronic obstructive pulmonary disease

${ }^{a}$ Key comorbidities included here are those predicted as risk factors for OIRD in the literature. These were collected as part of the medical history

Caucasians in both groups $(85.8 \%$ in the elderly and $76.6 \%$ in younger adults). The prevalence of medical comorbidities that are known to be associated with increased risk of OIRD [10] in the elderly and younger adults, respectively was: sleep apnea (17.4\% and $10.8 \%)$; chronic obstructive pulmonary disease, COPD $(10.0 \%$ and $2.5 \%)$; cardiac disease $(24.1 \%$ and $12.8 \%)$; diabetes mellitus (23.2\% and $11.4 \%)$ and hypertension $(72.2 \%$ and $29.8 \%$ ) (Table 2$)$. The distribution of obese $(49.8 \%)$ or non-obese patients (50.2\%) was comparable in the elderly group. Orthopedic surgery was more prevalent in the elderly (56.0 vs $19.9 \%$ in younger adults), while gynecological (2.9 vs. $22.4 \%$ ) and plastic surgery (0.8 vs. $12.0 \%)$, were more common in the younger adults (Supplement Figure 2a).

Obese $\left(B M I \geq 30 \mathrm{~kg} / \mathrm{m}^{2}\right)$ and non-obese $\left(B M I<30 \mathrm{~kg} / \mathrm{m}^{2}\right)$ patients: The mean $\pm \mathrm{SD}$ age was $56.2 \pm 13.8$ years in the obese group and $53.1 \pm 17.4$ years in the non-obese group with no clinically meaningful differences in gender, race, or baseline NRS pain score between the two groups (Table 1). The mean BMI in the obese group was $36.7 \pm 5.8 \mathrm{~kg} / \mathrm{m}^{2}$ and $25.3 \pm 3.3 \mathrm{~kg} / \mathrm{m}^{2}$ in the non-obese group. The prevalence of medical comorbidities known to increase risk of OIRD [10], in the obese and nonobese groups, respectively, was: sleep apnea (20.6\% and 6.4\%); diabetes mellitus (20.6\% and
10.8\%); COPD (5.7\% and 4.4\%), and hypertension $(55.8 \%$ and $33.7 \%$ ) (Table 2). Except for orthopedic surgery, which was more common in the obese group ( 40.0 vs. $24.9 \%$ in nonobese), the distribution of the other surgical types was comparable between the two groups (Supplement Figure 2b).

\section{Exposure to Oliceridine}

Overall, $52 \%$ of individuals received oliceridine by bolus dosing and $48 \%$ by PCA device (Table 3). The median [range] cumulative dose of oliceridine was 21.0 [0.9-22.3] $\mathrm{mg}$ (IQR $39.5 \mathrm{mg}$ ) with a median [range] duration of exposure of 21.4 [0-142.7] hours (IQR $41.6 \mathrm{~h}$ ).

Elderly ( $\geq 65$ years) and younger $(<65$ years) patients: PCA use was $68.9 \%$ in the elderly patients and $37.5 \%$ in younger adults; bolus dosing was $31.1 \%$ in the elderly and $62.5 \%$ in younger adults. The median [range] dose was 28.0 [1-154.5] mg (IQR $39.0 \mathrm{mg}$ ) in the elderly; 17.0 [0.9-223.5] $\mathrm{mg}$ (IQR $35.0 \mathrm{mg}$ ) in younger adults and median [range] duration of exposure was 39.1 [0-138.3] hours (IQR $41.2 \mathrm{~h}$ ) and 17.4 [0-142.7] hours (IQR $40.8 \mathrm{~h}$ ) in the elderly and younger adults, respectively (Table 3 ).

Obese $\quad\left(B M I \geq 30 \mathrm{~kg} / \mathrm{m}^{2}\right)$ and non-obese $\left(B M I<30 \mathrm{~kg} / \mathrm{m}^{2}\right)$ patients: Oliceridine was 
administered by PCA in $52.2 \%$ in the obese group and in $44.2 \%$ of the non-obese group; IV bolus administration was used in 47.8 and $55.8 \%$ of the obese and non-obese group, respectively. The median [range] cumulative dose of oliceridine was 23.0 [1-165.0] $\mathrm{mg}$ (IQR $38 \mathrm{mg}$ ) in the obese group and 20.0 [0.9-223.5] $\mathrm{mg}$ (IQR $41 \mathrm{mg}$ ) in the non-obese. The median [range] duration of exposure was 22.1 [0-142.7] hours (IQR $37.45 \mathrm{~h}$ ) and 20.8 [0-138.3] hours (IQR $48.4 \mathrm{~h}$ ), respectively in the obese and nonobese groups (Table 3 ).

\section{Effectiveness}

Change from baseline in NRS at $30 \mathrm{~min}$ was $-2.1 \pm 2.1$ in the elderly and $-2.2 \pm 2.4$ in the younger group. Likewise, the change from baseline in NRS at $30 \mathrm{~min}$ was $-2.1 \pm 2.3$ in the obese and $-2.2 \pm 2.3$ in the non-obese patients.

\section{Respiratory Events}

Opioid-induced respiratory depression (OIRD): None of the 724 surgical patients receiving IV oliceridine after surgery required administration of naloxone. Surgical patients who met the criteria of $\mathrm{RR}<10 \mathrm{bpm}$ was: $67 / 724(9.3 \%)$; and those who met the criteria of $\mathrm{SPO}_{2}<90 \%$ was $38 / 724(5.2 \%)$. The incidence of OIRD when using quantitative measures of $\mathrm{RR}<10 \mathrm{bpm}$ or $\mathrm{SPO}_{2}<90 \%$ was $13.7 \%$ (Fig. 1). No patient displayed a $\mathrm{RR}<10 \mathrm{bpm}$ and $\mathrm{SpO}_{2}<90 \%$ at the same time.

OIRD in the elderly ( $\geq 65$ years) and younger $(<65$ years) patients: There were no differences in the incidence of OIRD between the elderly and younger adults [10.8 vs. $15.1 \%$, OR 0.68 $(0.42,1.1), p=0.11]$ (Fig. 1). The incidence of OIRD displayed an inverted U-shape with an incidence of $10.3 \%$ or less in patients $<40$ years of age, $19.4 \%$ in patients aged $>40-50$ years, $16.4 \%$ in patients aged $>50-60$ years, $12.3 \%$ in

Table 3 Exposure to oliceridine

\begin{tabular}{|c|c|c|c|c|c|c|}
\hline & $\begin{array}{l}\text { ALL } \\
\text { surgical } \\
\text { patients }\end{array}$ & Age $<65$ years & Age $\geq 65$ years & $\begin{array}{l}\mathrm{BMI}<30 \mathrm{~kg} / \\
\mathrm{m}^{2}\end{array}$ & $\begin{array}{l}\text { BMI } \geq 30 \mathrm{~kg} / \\
\mathrm{m}^{2}\end{array}$ & $\begin{array}{l}\text { Age } \geq 65 \text { years } \\
\text { with } \\
\text { BMI } \geq 30 \mathrm{~kg} / \\
\mathrm{m}^{2}\end{array}$ \\
\hline$N$ & 724 & 483 & 241 & 389 & 335 & 120 \\
\hline Bolus, $n$ (\%) & $377(52.0)$ & $302(62.5)$ & $75(31.1)$ & $217(55.8)$ & $160(47.8)$ & $33(27.5)$ \\
\hline $\mathrm{PCA}, n(\%)$ & $347(47.9)$ & $181(37.5)$ & $166(68.9)$ & $172(44.2)$ & $175(52.2)$ & $87(72.5)$ \\
\hline \multicolumn{7}{|c|}{ Cumulative dose of oliceridine (mg) } \\
\hline Mean \pm SD & $31.2 \pm 31.3$ & $29.3 \pm 32.3$ & $34.8 \pm 29.0$ & $30.8 \pm 31.7$ & $31.6 \pm 31.0$ & $37.1 \pm 28.1$ \\
\hline \multirow{3}{*}{$\begin{array}{l}\text { Median (min, } \\
\max ) / \\
\text { interquartile } \\
\text { range }\end{array}$} & 21.0 & 17.0 & 28.0 & 20.0 & 23.0 & 34.3 \\
\hline & $(0.9,22.3)$ & $(0.9,223.5)$ & $(1,154.5)$ & $(0.9,223.5)$ & $(1,165.0)$ & $(1,144.5)$ \\
\hline & 39.5 & 35.0 & 39.0 & 41.0 & 38.0 & 42.5 \\
\hline \multicolumn{7}{|c|}{ Duration of exposure $(\mathrm{h})$} \\
\hline Mean $\pm S D$ & $30.3 \pm 26.8$ & $26.3 \pm 26.5$ & $38.2 \pm 25.8$ & $30.7 \pm 27.5$ & $29.7 \pm 26.0$ & $39.8 \pm 24.1$ \\
\hline \multirow{3}{*}{$\begin{array}{l}\text { Median (min, } \\
\text { max)/ } \\
\text { interquartile } \\
\text { range }\end{array}$} & 21.4 & 17.4 & 39.1 & 20.8 & 22.1 & 39.6 \\
\hline & $(0,142.7)$ & $(0,142.7)$ & $(0,138.3)$ & $(0,138.3)$ & $(0,142.7)$ & $(0,130.8)$ \\
\hline & 41.6 & 40.8 & 41.2 & 48.4 & 37.5 & 41.9 \\
\hline
\end{tabular}




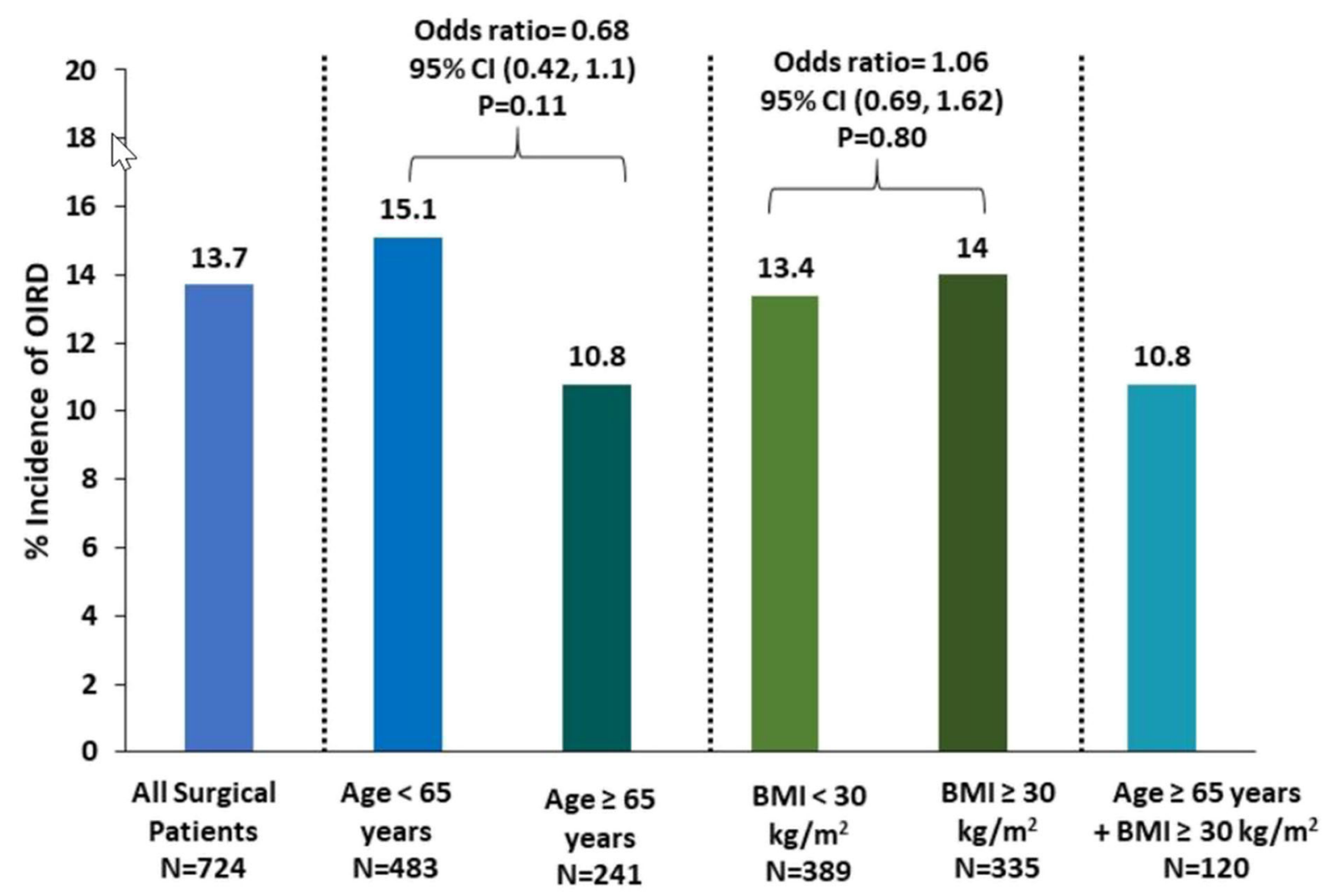

Fig. 1 Incidence of OIRD through $48 \mathrm{~h}$ of cumulative dose exposure. OIRD defined as any of the following: respiratory rate $(\mathrm{RR})<10 \mathrm{bpm}$ (including $\mathrm{RR}<8 \mathrm{bpm}$ ), oxygen saturation $\left(\mathrm{SpO}_{2}\right)<90 \%$ (including $\mathrm{SPO}_{2}<85 \%$ )

patients aged $>60-70$ years and $12.2 \%$ in patients aged $>70$ years (Fig. 2).

OIRD in the obese (BMI $\geq 30 \mathrm{~kg} / \mathrm{m}^{2}$ ) and nonobese $\left(B M I<30 \mathrm{~kg} / \mathrm{m}^{2}\right)$ patients: The incidence of OIRD did not differ in the obese and non-obese groups [14.0 vs. $13.4 \%$, OR $1.06(0.69,1.62)$, $p=0.80]$ (Fig. 1). The incidence of OIRD was $10.3 \%$ in the morbidly obese subjects $\left(\mathrm{BMI}>40 \mathrm{~kg} / \mathrm{m}^{2}\right), 13.5 \%$ in the group with BMI $<25 \mathrm{~kg} / \mathrm{m}^{2}, 13.4 \%$ in patients with BMI $25-30 \mathrm{~kg} / \mathrm{m}^{2}$, and $14.9 \%$ in the group with BMI $30-40 \mathrm{~kg} / \mathrm{m}^{2}$ (Fig. 3).

OIRD in elderly patients $(\geq 65$ years) with $B M I \geq 30 \mathrm{~kg} / \mathrm{m}^{2}$ (very high risk group) $(n=120)$ : The incidence of OIRD in the elderly with BMI $\geq 30 \mathrm{~kg} / \mathrm{m}^{2}$ was $10.8 \%$ (Fig. 1 ).

Demographics and clinical characteristics of patients with and without OIRD within the age and BMI categories: As shown in Table 4, in patients $\geq 65$ years with OIRD, the incidence of COPD was $19.2 \%$, and in patients without
OIRD, the incidence was $8.8 \%$. The rates of other medical comorbidities (e.g., sleep apnea) were comparable between OIRD and non-OIRD patients. The use of concomitant benzodiazepines and gabapentinoids was high in both elderly as well as obese patients experiencing OIRD (Table 4).

\section{Predictors for OIRD Using Multivariate Logistic Regression Models}

In the multivariate logistic models utilizing the $p=0.1$ staying criterion, baseline pain score $\geq 6$ NRS [OR 1.6 $(1.0,2.4) p=0.0499]$, oliceridine administration via PCA, [OR 1.9 (1.2, 3.1), $p=0.005]$, and concomitant use of benzodiazepine and/or gabapentinoids [OR 1.6 (1.0, 2.6), $p=0.045]$, were associated with significantly increased odds of experiencing OIRD (Fig. 4). Orthopedic surgery was associated with a significantly lower odds of experiencing OIRD [OR $0.53(0.3,0.92) p=0.024]$. Of note, among 


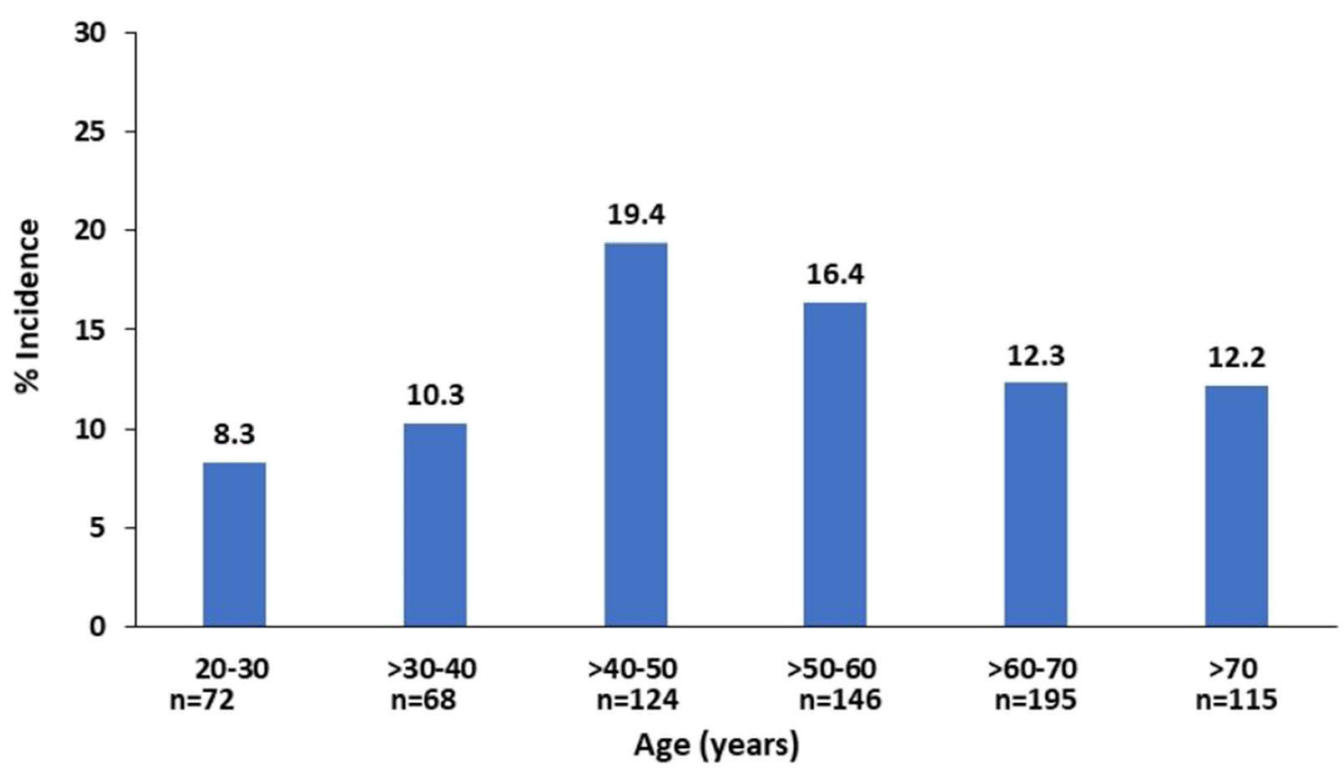

Fig. 2 Incidence of OIRD by age categories. OIRD defined as any of the following: respiratory rate $(\mathrm{RR})<10 \mathrm{bpm}$ (including $\mathrm{RR}<8 \mathrm{bpm}$ ), oxygen saturation $\left(\mathrm{SpO}_{2}\right)<90 \%$ (including $\mathrm{SPO}_{2}<85 \%$ )

the 231 patients who underwent orthopedic surgery, 154 patients $(66.7 \%)$ received oliceridine via PCA administration.

\section{DISCUSSION}

We found that oliceridine, a G-protein-biased $\mu$ opioid receptor agonist, did not increase the risk of OIRD in patients with advanced age ( $\geq 65$ years) and/or high BMI $\left(\geq 30 \mathrm{~kg} / \mathrm{m}^{2}\right)$ when administered for postoperative pain. Overall, $13.7 \%$ of all 724 subjects experienced OIRD defined by a respiratory rate $<10 \mathrm{bpm}$ or oxygen saturation $<90 \%$, with none requiring naloxone for reversal of OIRD [29]. Clinical effectiveness was comparable in the different age and BMI categories, with oliceridine use being associated with a rapid onset and a potent analgesic effect of a two-point reduction in the pain score within $30 \mathrm{~min}$.

Advanced age and obesity (BMI $\geq 30 \mathrm{~kg} / \mathrm{m}^{2}$ ) are well recognized risk factors for developing OIRD [8, 10, 30-32], though the pooled estimate in a recently published meta-analysis failed to find any significant association with age or BMI with OIRD [9]. Physiological changes related to aging influencing pharmacokinetics and pharmacodynamics of drugs, including decreased clearance, along with a higher prevalence of comorbidities [33], predispose elderly individuals to increased sensitivity to respiratory depression from opioids [10]. In contrast, obesity is a risk factor for obstructive sleep apnea with the prevalence of sleep apnea in obese patients nearly twice that of averageweight adults [34]. Patients with obstructive sleep apnea experience an increased sensitivity to the effects of opioids that may predispose them to a higher risk of OIRD $[8,35]$. A large meta-analysis of 13 studies, including 11 retrospective reviews/case studies and two observational studies, reported that patients aged 61-70 years had 2.8 times the risk of OIRD (95\% CI 1.2-6.6) compared with patients aged 16-45 years [10]. The risk increased with increasing age; patients aged $71-80$ years had 5.4 times the risk (95\% CI 2.4-11.8) and those aged more than 80 years had 8.7 times the risk $(95 \%$ CI 3.8-20.0) compared to patients $16-45$ years of age [10]. Although obesity is reported as one of the risk factors for OIRD in studies or in claims databases $[8,10,30,36]$, there are no data available demonstrating the true incidence in obese individuals compared to non-obese individuals. In our analysis, the elderly and patients 


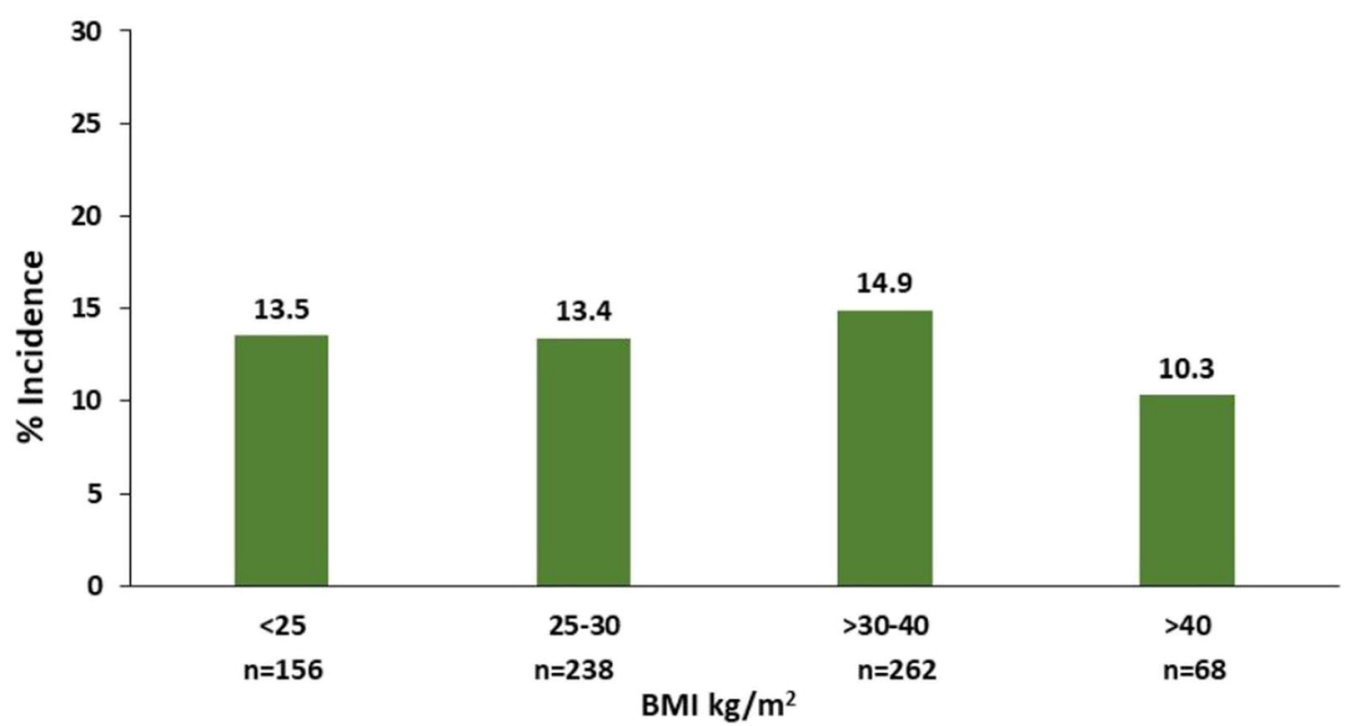

Fig. 3 Incidence of OIRD by BMI categories. OIRD defined as any of the following: respiratory rate $(\mathrm{RR})<10 \mathrm{bpm}$ (including $\mathrm{RR}<8 \mathrm{bpm}$ ), oxygen saturation $\left(\mathrm{SpO}_{2}\right)<90 \%$ (including $\mathrm{SPO}_{2}<85 \%$ )

with a $\mathrm{BMI} \geq 30 \mathrm{~kg} / \mathrm{m}^{2}$ had a higher incidence of comorbidities compared to younger adults, or individuals with a $\mathrm{BMI}<30 \mathrm{~kg} / \mathrm{m}^{2}$, respectively, including sleep apnea, diabetes, and hypertension. All three comorbid conditions have been reported to increase the risk of postoperative OIRD [10]. The lack of an increased incidence of OIRD with the postoperative use of oliceridine in older or obese subjects with increased comorbidity burden relative to younger or non-obese adults, respectively, with lower rates of comorbidities, suggests that oliceridine may represent a safer treatment option in these two high-risk patient populations than conventional opioids. This was further supported by the findings of low OIRD incidence $(10.8 \%)$ in the elderly patients who were also obese, a subgroup considered at very high risk for OIRD. Notably, none of the 29 elderly and obese patients who also had obstructive sleep apnea (24.2\%) developed OIRD. Finally, advanced age ( $\geq 65$ years) or a high BMI $\left(\geq 30 \mathrm{~kg} / \mathrm{m}^{2}\right)$ was not associated with a significant increase in the risk for OIRD in the multivariate analysis.

The recently reported failure of multimodal analgesia to reduce postoperative opioid use $[16,17]$ as well as the growing opioid epidemic [37] further highlight the clinical need for effective opioids with a safer profile in high-risk patients. Conventional opioids that bind to the $\mu$-opioid receptor activate two distinct pathways, the G-protein and $\beta$-arrestin [21]. Preclinical studies suggest that the activation of the G-protein pathway results in analgesic effect, while the activation of the $\beta$-arrestin pathway may be associated with opioid-related adverse events, including OIRD [22-24], though recent findings suggest a more complex role of the $\beta$ arrestin pathway [38]. Selective (biased) opioidreceptor agonists may offer a better safety profile while providing adequate analgesia. Oliceridine (TRV130; Trevena Inc., Chesterbrook, PA, USA) represents a new class of IV $\mu$-opioid receptor agonists and nonclinical findings show that it is G-protein biased, with substantially reduced recruitment of $\beta$-arrestin pathway [24-27]. Consistent with this G-protein pathway selectivity, IV oliceridine was found to provide effective analgesia with improved respiratory and gastrointestinal safety profile in nonclinical studies when compared to morphine [24]. In randomized clinical studies, oliceridine provided rapid analgesia with favorable respiratory and gastrointestinal tolerability when used at demand doses of $0.1,0.35$, or $0.5 \mathrm{mg}$ for moderate-to-severe pain following bunionectomy [39] and abdominoplasty [40]. 
Table 4 Characteristics of surgical patients experiencing OIRD compared to those with no OIRD among elderly (age $\geq 65$ years) or obese (BMI $\geq 30 \mathrm{~kg} / \mathrm{m}^{2}$ ) patients

\begin{tabular}{|c|c|c|c|c|c|c|}
\hline \multirow[t]{2}{*}{ Characteristic } & \multicolumn{2}{|c|}{ Age $\geq 65$ years } & \multicolumn{2}{|c|}{$\mathrm{BMI} \geq 30 \mathrm{~kg} / \mathrm{m}^{2}$} & \multicolumn{2}{|c|}{$\begin{array}{l}\text { Age } \geq 65 \text { years with } \\
\text { BMI } \geq 30 \mathrm{~kg} / \mathrm{m}^{2}\end{array}$} \\
\hline & $\begin{array}{l}\text { OIRD } \\
(n=26)\end{array}$ & $\begin{array}{l}\text { No OIRD } \\
(n=215)\end{array}$ & $\begin{array}{l}\text { OIRD } \\
(n=47)\end{array}$ & $\begin{array}{l}\text { No OIRD } \\
(n=288)\end{array}$ & $\begin{array}{l}\text { OIRD } \\
(n=13)\end{array}$ & $\begin{array}{l}\text { No OIRD } \\
(n=107)\end{array}$ \\
\hline Female gender, $n(\%)$ & $14(53.8)$ & $122(56.7)$ & $30(63.8)$ & $187(64.9)$ & $7(53.9)$ & $65(60.8)$ \\
\hline Mean age $\pm S D$, years & $72.3 \pm 5.25$ & $71.1 \pm 4.92$ & $55.2 \pm 13.0$ & $56.4 \pm 13.92$ & $70.1 \pm 3.5$ & $70.4 \pm 4.6$ \\
\hline Median age & 72 & 70 & 58 & 58 & 70 & 69 \\
\hline Range & $65-82$ & $65-89$ & $26-76$ & $19-84$ & $65-76$ & $65-84$ \\
\hline Interquartile range & 7 & 7 & 20 & 21 & 4 & 6 \\
\hline \multicolumn{7}{|l|}{ Age group, years, $n(\%)$} \\
\hline$<65$ & - & - & $34(72.3)$ & $181(62.9)$ & & \\
\hline$\geq 65$ & $26(100.0)$ & $\begin{array}{l}215 \\
\quad(100.0)\end{array}$ & $13(27.7)$ & $107(37.2)$ & & \\
\hline $\begin{array}{l}\text { Mean } \mathrm{BMI} \pm \mathrm{SD}, \mathrm{kg} / \\
\mathrm{m}^{2}\end{array}$ & $30.2 \pm 6.2$ & $30.7 \pm 6.5$ & $36.0 \pm 5.7$ & $36.8 \pm 5.8$ & $34.4 \pm 5.1$ & $35.8 \pm 4.7$ \\
\hline Median BMI & 29.8 & 29.8 & 34.4 & 35.3 & 33 & 34.7 \\
\hline Range & $16.8-48.3$ & $12.8-58.2$ & $30-56.1$ & $30,61.6$ & $30-48.3$ & $30-58.2$ \\
\hline Interquartile range & 6.1 & 8.7 & 6.4 & 6.8 & 4.1 & 4.9 \\
\hline \multicolumn{7}{|l|}{ BMI group, $\mathrm{kg} / \mathrm{m}^{2}, n(\%)$} \\
\hline$<30$ & $13(50.0)$ & $108(50.2)$ & - & - & & \\
\hline$\geq 30$ & $13(50.0)$ & $107(49.8)$ & $47(100.0)$ & $305(100.0)$ & & \\
\hline $\begin{array}{l}\text { Baseline pain score, } \\
\text { mean } \pm S D\end{array}$ & $6.4 \pm 2.0$ & $5.9 \pm 2.1$ & $6.7 \pm 2.0$ & $6.2 \pm 2.3$ & $6.8 \pm 2.0$ & $5.9 \pm 2.1$ \\
\hline \multicolumn{7}{|l|}{ Median baseline pain } \\
\hline Score & 7.0 & 5.0 & 7.0 & 5.0 & 6.0 & 5.0 \\
\hline Range & $4-10$ & $0-10$ & $4-10$ & $0-10$ & $4-10$ & $2-10$ \\
\hline Interquartile range & 3 & 4 & 3 & 4 & 3 & 3 \\
\hline \multicolumn{7}{|c|}{ Medical comorbidities associated with higher risk of OIRD } \\
\hline Sleep apnea, $n(\%)$ & $3(11.5)$ & $39(18.1)$ & $7(14.9)$ & $62(21.5)$ & 0 & $29(27.1)$ \\
\hline COPD, $n(\%)$ & $5(19.2)$ & $19(8.8)$ & $5(10.6)$ & $14(4.9)$ & $3(23.1)$ & $11(10.3)$ \\
\hline Cardiac disorders, $n(\%)$ & $10(38.5)$ & $48(22.3)$ & $10(21.3)$ & $48(16.7)$ & $4(30.8)$ & $22(20.6)$ \\
\hline Diabetes mellitus, $n(\%)$ & $7(26.9)$ & $49(22.8)$ & $11(23.4)$ & $58(20.1)$ & $4(30.8)$ & $22(20.6)$ \\
\hline Hypertension, $n(\%)$ & $20(76.9)$ & $154(71.6)$ & $28(59.6)$ & $159(55.2)$ & $13(100.0)$ & $84(78.5)$ \\
\hline
\end{tabular}

Concomitant medications associated with risk of OIRD 
Table 4 continued

\begin{tabular}{|c|c|c|c|c|c|c|}
\hline \multirow[t]{2}{*}{ Characteristic } & \multicolumn{2}{|c|}{ Age $\geq 65$ years } & \multicolumn{2}{|c|}{$\mathrm{BMI} \geq 30 \mathrm{~kg} / \mathrm{m}^{2}$} & \multicolumn{2}{|c|}{$\begin{array}{l}\text { Age } \geq 65 \text { years with } \\
\text { BMI } \geq 30 \mathrm{~kg} / \mathrm{m}^{2}\end{array}$} \\
\hline & $\begin{array}{l}\text { OIRD } \\
(n=26)\end{array}$ & $\begin{array}{l}\text { No OIRD } \\
(n=215)\end{array}$ & $\begin{array}{l}\text { OIRD } \\
(n=47)\end{array}$ & $\begin{array}{l}\text { No OIRD } \\
(n=288)\end{array}$ & $\begin{array}{l}\text { OIRD } \\
(n=13)\end{array}$ & $\begin{array}{l}\text { No OIRD } \\
(n=107)\end{array}$ \\
\hline Benzodiazepines $^{\mathrm{a}}, n(\%)$ & $10(38.5)$ & $49(22.8)$ & $13(27.7)$ & $69(24.0)$ & $6(46.2)$ & $25(23.4)$ \\
\hline Gabapentanoids ${ }^{\mathrm{b}}, n(\%)$ & $15(57.7)$ & $60(27.9)$ & $15(31.9)$ & $62(21.5)$ & $9(69.2)$ & $35(32.7)$ \\
\hline
\end{tabular}

${ }^{a}$ Includes medications of alprazolam, clonazepam, diazepam, lorazepam, midazolam, midazolam hydrochloride, temazepam, zolpidem, and zolpidem tartrate

b Includes medications of gabapentin or pregabalin

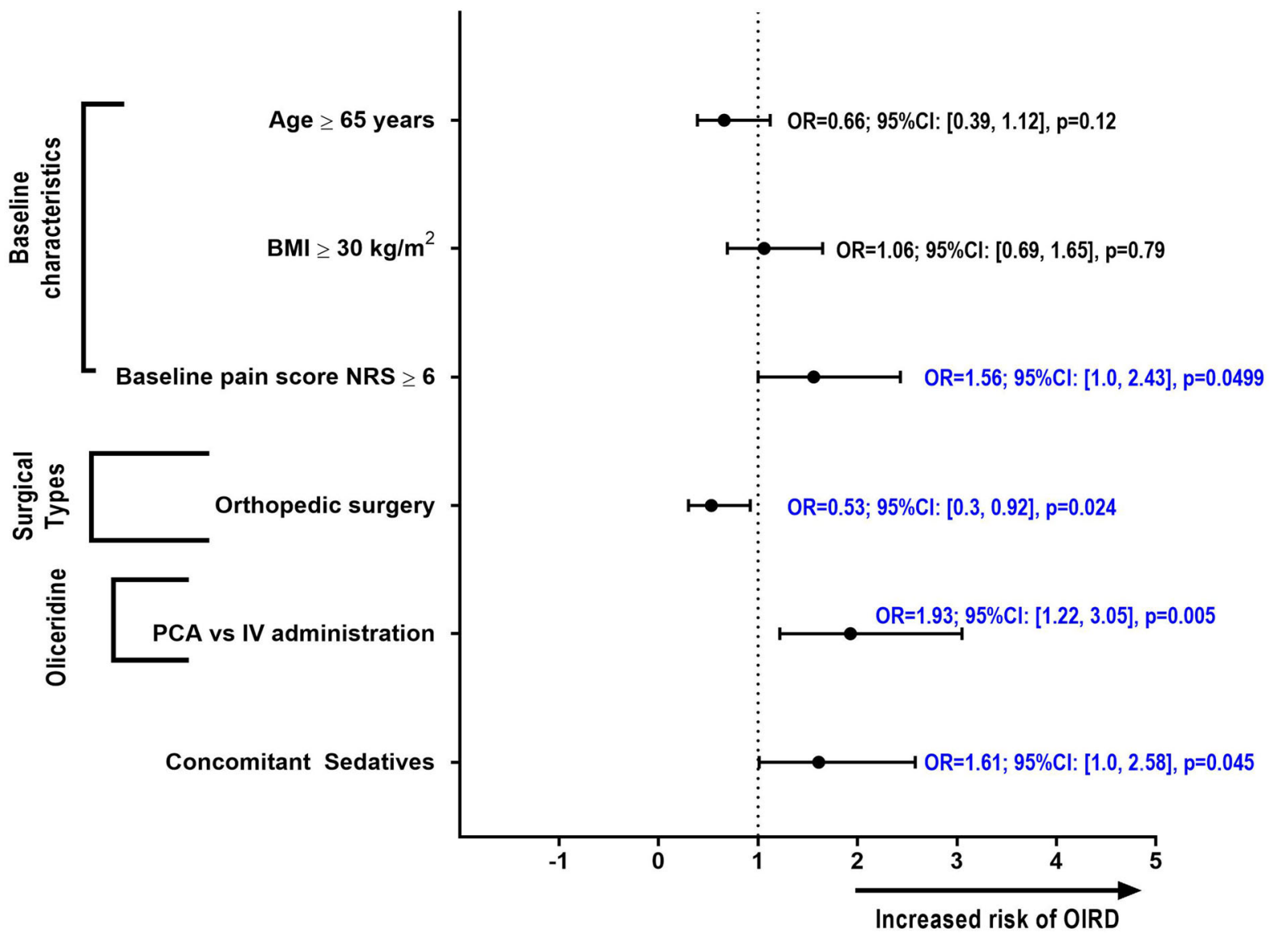

Fig. 4 Risk factors associated with OIRD in the multivariate regression model (using backward elimination). A backward elimination (or backward deletion) process was used in the regression model, where all predictor variables were entered into the equation first and the variable that contributes the least to the regression model was eliminated if they were above the specified stay criterion of $p=0.1$. Concomitant sedatives included in the model were gabapentinoids (gabapentin, pregabalin) and benzodiazepines (alprazolam, clonazepam, diazepam, lorazepam, midazolam, midazolam hydrochloride, temazepam, zolpidem, and zolpidem tartrate) 
In a utility function analysis, compared with morphine, oliceridine was found to offer a higher probability of providing analgesia than producing respiratory depression, while morphine had a higher probability of producing respiratory depression than providing analgesia [41]. Finally, oliceridine pharmacokinetic studies show no significant differences in the clearance of oliceridine in the older ( $\geq 65$ years) as compared to younger patients [42], possibly contributing to the lack of increased incidence of OIRD in the elderly.

The multivariate analysis performed in the current study identified concomitant administration of sedatives (benzodiazepines and/or gabapentinoids), administration via PCA and baseline pain score $\geq 6$ in the NRS scale as significantly associated with OIRD. Conversely, undergoing orthopedic surgery was associated with $\sim 50 \%$ lower odds of experiencing OIRD. It should be noted, however, that the interaction of surgical type with PCA dosing and baseline pain score was not studied in the logistic regression model.

Benzodiazepines are commonly used preoperatively due to their amnesic and anxiolytic effect $[43,44]$. Likewise, in the current era of use of multimodal analgesia in ERAS protocols, gabapentinoids are commonly used to reduce postoperative pain and lower opioid consumption $[43,45]$. The concomitant administration of benzodiazepines or gabapentinoids with opioids can have a synergistic effect thereby increasing the risk for OIRD [10, 43, 46, 47]. In the current analysis, concomitant sedative administration significantly increased the risk of OIRD [OR $1.6(1.0,2.6) ; p<0.05]$.

Factors related to dosing and route of administration have been reported to influence the risk of OIRD, with higher opioid doses or use of multiple different opioids reported to be significantly associated with a higher incidence of OIRD [9]. In the current analysis, as in prior studies, administration of oliceridine via PCA was associated with a significantly increased risk of OIRD compared to IV bolus administration (OR 1.9 [95\% CI 1.2, 3.1]; $p=0.005$ ). It has been suggested that use of PCA may lead to a higher total dose of opioids and thus contribute to the increased risk [9]. However, in the current study, the cumulative mean dose of oliceridine did not influence the risk of OIRD. Our finding that oliceridine administration via PCA increased the risk for OIRD, while the cumulative dose of oliceridine did not influence the risk of OIRD, may be attributed to other confounding factors not evaluated in this analysis, including dosing intervals with clustering of doses over a shorter period of time. This mechanism is further supported by the association of high baseline pain score with OIRD that, to the best of our knowledge, has not been previously reported. The lack of significant association of cumulative dose and duration of administration with OIRD while baseline pain score and method of administration showed significant association suggest that the pattern of dosing might be more influential on the rate of OIRD than total dose and duration. A higher baseline pain score could have led to an increase of self-administered doses and therefore rapidly increase the dose received over a shorter period of time increasing the risk of OIRD while other patients with the same total cumulative dose received drug at a slower rate resulting in our finding of lack of association of cumulative dose with OIRD.

There is limited information in the literature regarding the influence of type of surgery on the risk of OIRD, with a recent meta-analysis failing to find an association between type of surgery and risk of OIRD [9]. The revised Guidelines on "Monitoring for Opioid-Induced Advancing Sedation and Respiratory Depression" issued by the American Society for Pain Management Nursing (ASPMN) identifies the surgical site of head, neck, chest and upper abdomen as a risk factor for OIRD [43]. In our analysis, none of the surgical types was significantly associated with increased risk of OIRD although patients undergoing orthopedic surgery had $\sim 50 \%$ lower odds of experiencing OIRD. It is possible that the higher utilization of regional anesthesia for orthopedic surgeries could have contributed to these findings [43]. 


\section{Limitations}

The current analysis is retrospective and exploratory in nature based on the data from the ATHENA trial. This study was an open-label study with no control arm, thereby allowing potential bias in the findings. Since the ATHENA study did not have any a-priori criteria for eligibility regarding BMI, advanced age, or comorbid conditions, the baseline parameters identified in this analysis were limited to the available parameters post-enrollment. Being a retrospective analysis, a power analysis was not performed to determine whether there were sufficient numbers within each type of surgery, dosing administration regimen, comorbid conditions or any of the baseline characteristics to find an association with OIRD, if present. To avoid the statistical model to be over-parameterized, leading to quasi-complete conversion or non-convergence of the model, additional interaction terms were excluded from the model. Thus, the interaction between surgical types with PCA dosing and baseline NRS scores was not studied. In addition, the lack of availability of all predictive risk parameters did not allow evaluation of possible additional risk factors such as renal or hepatic impairment, both of which have been reported as risk factors for the development of severe OIRD $[9,48]$. Lastly, the ATHENA study did not use "The STOP-Bang questionnaire" that screens for the risk of obstructive sleep apnea (OSA) in the preoperative period.

The strengths of this study include the less restricted nature of the ATHENA trial with respect to patient eligibility criteria, treatment protocol requirements, patient population and mode of administration; the trial therefore represents a "real-world" setting. This along with a large sample size of patients undergoing a variety of surgeries utilizing both IV bolus or PCA administration of oliceridine allows for better generalization of the findings to a broad surgical population.

\section{CONCLUSIONS}

The use of oliceridine for postsurgical analgesia in patients with advanced age and/or increased BMI experiencing moderate-to-severe pain was not associated with increased risk of respiratory depression. Oliceridine use may be clinically appropriate for use in obese or elderly patients at high risk for OIRD. These data should be confirmed by future trials that evaluate oliceridine in comparison with conventional opioids with the inclusion of prospective indices of respiratory compromise and continuous respiratory monitoring tools in the postoperative setting.

\section{ACKNOWLEDGEMENTS}

Funding. The open-label ATHENA trial (NCT02656875) was sponsored by Trevena, Inc., Chesterbrook, PA. The exploratory analysis described here was conducted by Trevena, Inc. The funding for the Journal's Rapid Service Fee was provided by the study sponsor, Trevena, Inc.

Editorial Assistance. The authors would like to thank Kanaka Sridharan, M.S. R.Ph, an employee of Trevena Inc., for editorial support and creation of figures. The authors would also like to thank Michael J. Fossler, Pharm. D., Ph. D., F.C.P, Vice President, Clinical Development and Quantitative Sciences, Trevena, Inc., for providing the direction in the conduct of the multivariate analysis.

Authorship. All named authors meet the International Committee of Medical Journal Editors (ICMJE) criteria for authorship for this article, take responsibility for the integrity of the work as a whole, and have given their approval for this version to be published.

Authorship Contributions. MB provided the concept for this analysis, interpretation of the data, and wrote the first draft of the manuscript. $\mathrm{CM}$ conducted the statistical analysis. GBH, KAC, SDB, PHP, LW, MAD, and ASH 
contributed to the interpretation of the data as it relates to the clinical implications and provided additional input to the discussion section. All authors approved the final draft that is submitted to the journal.

Prior Presentation. This analysis was based on work that was previously presented at the 2019, Anesthesiology Annual Meeting, October 19-23, Orlando, FL, A 2228. Abstract available at http://www.asaabstracts.com/strands/asaabstra cts/abstract.htm?year=2019\&index=18\&absnum $=1619$.

Disclosures. Marek Brzezinski, Gregory B Hammer, Keith A. Candiotti, Sergio D. Bergese, Peter H. Pan, Michael H. Bourne M.D and Ashraf S. Habib were investigators of the ATHENA (NCT02656875) study. Cathy Michalsky, Linda Wase, and Mark A. Demitrack are employees at Trevena, Inc. At the time of conduct of the ATHENA study, Sergio D. Bergese was affiliated with the Ohio State University Wexner Medical Center; that was the participating site for the trial.

Compliance with Ethics Guidelines. All procedures performed in the ATHENA (NCT02656875) study were in accordance with the International Conference on Harmonization Good Clinical Practice guidelines and ethical principles that have their origin in the Declaration of Helsinki. Protocols were approved by an Independent Ethics Committee before eligibility screening. Informed consent was obtained from all individual participants included in the study, as specified in the ATHENA publication.

Data Availability. All data generated or analyzed in this exploratory analysis are included in this published article/and in the supplementary information.

Open Access. This article is licensed under a Creative Commons Attribution-NonCommercial 4.0 International License, which permits any non-commercial use, sharing, adaptation, distribution and reproduction in any medium or format, as long as you give appropriate credit to the original author(s) and the source, provide a link to the Creative Commons licence, and indicate if changes were made. The images or other third party material in this article are included in the article's Creative Commons licence, unless indicated otherwise in a credit line to the material. If material is not included in the article's Creative Commons licence and your intended use is not permitted by statutory regulation or exceeds the permitted use, you will need to obtain permission directly from the copyright holder. To view a copy of this licence, visit http://creativecommons.org/licenses/by$\mathrm{nc} / 4.0 /$.

\section{REFERENCES}

1. Garimella V, Cellini C. Postoperative pain control. Clin Colon Rectal Surg. 2013;26(3):191-6.

2. Chou R, Gordon DB, de Leon-Casasola OA, Rosenberg JM, Bickler S, Brennan T, et al. Management of postoperative pain: a clinical practice guideline from the American Pain Society, the American Society of Regional Anesthesia and Pain Medicine, and the American Society of Anesthesiologists' Committee on Regional Anesthesia, Executive Committee, and Administrative Council. J Pain Off J Am Pain Soc. 2016;17(2):131-57.

3. Sinatra R. Causes and consequences of inadequate management of acute pain. Pain Med. 2010;11(12): 1859-71.

4. Gan TJ. Poorly controlled postoperative pain: prevalence, consequences, and prevention. J Pain Res. 2017;10:2287-98.

5. Stein C. New concepts in opioid analgesia. Expert Opin Investig Drugs. 2018;27(10):765-75.

6. Overholser BR, Foster DR. Opioid pharmacokinetic drug-drug interactions. Am J Manag Care. 2011;17(Suppl 11):S276-87.

7. Ayad S, Khanna AK, Iqbal SU, Singla N. Characterisation and monitoring of postoperative respiratory depression: current approaches and future considerations. Br J Anaesth. 2019;123(3):378-91.

8. Dahan A, Aarts L, Smith TW. Incidence, reversal, and prevention of opioid-induced respiratory depression. Anesthesiology. 2010;112(1):226-38. 
9. Gupta K, Nagappa M, Prasad A, Abrahamyan L, Wong J, Weingarten TN, et al. Risk factors for opioid-induced respiratory depression in surgical patients: a systematic review and meta-analyses. BMJ Open. 2018;8(12):e024086.

10. Gupta K, Prasad A, Nagappa M, Wong J, Abrahamyan L, Chung FF. Risk factors for opioid-induced respiratory depression and failure to rescue: a review. Curr Opin Anaesthesiol. 2018;31(1):110-9.

11. Overdyk F, Dahan A, Roozekrans M, van der Schrier R, Aarts L, Niesters M. Opioid-induced respiratory depression in the acute care setting: a compendium of case reports. Pain Manag. 2014;4(4):317-25.

12. Kinjo S, Sands LP, Lim E, Paul S, Leung JM. Prediction of postoperative pain using path analysis in older patients. J Anesth. 2012;26(1):1-8.

13. Pedersen C, Troensegaard H, Laigaard J, Koyuncu S, Schrøder HM, Overgaard S, Mathiesen O, Karlsen APH. Differences in patient characteristics and external validity of randomized clinical trials on pain management following total hip and knee arthroplasty: a systematic review. Reg Anesth Pain Med. 2020;45(9):709-15.

14. Wardhan R, Chelly J. Recent advances in acute pain management: understanding the mechanisms of acute pain, the prescription of opioids, and the role of multimodal pain therapy. F1000Research. 2017;6:2065.

15. Moningi S, Patki A, Padhy N, Ramachandran G. Enhanced recovery after surgery: an anesthesiologist's perspective. J Anaesthesiol Clin Pharmacol. 2019;35(Suppl 1):S5-13.

16. Echeverria-Villalobos $M$, Stoicea N, Todeschini $A B$, Fiorda-Diaz J, Uribe AA, Weaver T, et al. Enhanced recovery after surgery (ERAS): a perspective review of postoperative pain management under ERAS pathways and its role on opioid crisis in the United States. Clin J Pain. 2020;36(3):219-26.

17. Maheshwari K, Avitsian R, Sessler DI, Makarova N, Tanios M, Raza S, et al. Multimodal analgesic regimen for spine surgery: a randomized placebo-controlled trial. Anesthesiology. 2020;132(5): 992-1002.

18. None. Postsurgical Pain 2020 [cited 2020 July 21]. https://www.cdc.gov/acute-pain/postsurgical-pain/ index.html. Accessed 21 July 2020.

19. Yang R, Wolfson M, Lewis MC. Unique aspects of the elderly surgical population: an anesthesiologist's perspective. Geriatr Orthop Surg Rehabil. 2011;2(2):56-64.
20. Ri M, Aikou S, Seto Y. Obesity as a surgical risk factor. Ann Gastroenterol Surg. 2017;2(1):13-21.

21. Valentino RJ, Volkow ND. Untangling the complexity of opioid receptor function. Neuropsychopharmacology. 2018;43(13):2514-20.

22. Bohn LM, Lefkowitz RJ, Gainetdinov RR, Peppel K, Caron MG, Lin FT. Enhanced morphine analgesia in mice lacking beta-arrestin 2. Science. 1999;286(5449):2495-8.

23. Raehal KM, Walker JK, Bohn LM. Morphine side effects in beta-arrestin 2 knockout mice. J Pharmacol Exp Ther. 2005;314(3):1195-201.

24. DeWire SM, Yamashita DS, Rominger DH, Liu G, Cowan CL, Graczyk TM, et al. A G protein-biased ligand at the mu-opioid receptor is potently analgesic with reduced gastrointestinal and respiratory dysfunction compared with morphine. J Pharmacol Exp Ther. 2013;344(3):708-17.

25. Chen XT, Pitis P, Liu G, Yuan C, Gotchev D, Cowan $\mathrm{CL}$, et al. Structure-activity relationships and discovery of a $\mathrm{G}$ protein-biased mu-opioid receptor ligand, [(3-methoxythiophen-2-yl)methyl](\{2-[(9R)9-(pyridin-2-yl)-6-oxaspiro-[4.5]decan-9-yl]ethyl\})amine (TRV130), for the treatment of acute severe pain. J Med Chem. 2013;56(20):8019-31.

26. Raehal KM, Schmid CL, Groer CE, Bohn LM. Functional selectivity at the mu-opioid receptor: implications for understanding opioid analgesia and tolerance. Pharmacol Rev. 2011;63(4):1001-19.

27. Schmid CL, Kennedy NM, Ross NC, Lovell KM, Yue $\mathrm{Z}$, Morgenweck J, et al. Bias factor and therapeutic window correlate to predict safer opioid analgesics. Cell. 2017;171(5):1165-75.e13.

28. Bergese SD, Brzezinski M, Hammer GB, Beard TL, Pan PH, Mace SE, et al. ATHENA: A Phase 3, Openlabel study of the safety and effectiveness of oliceridine (TRV130), a G-protein selective agonist at the mu-opioid receptor, in patients with moderate to severe acute pain requiring parenteral opioid therapy. J Pain Res. 2019;12:3113-26.

29. Bergese SD, Brzezinski M, Hammer GB, Beard TL, Pan PH, Mace SE, et al. ATHENA: a phase 3, openlabel study of the safety and effectiveness of oliceridine (TRV130), a G-protein selective agonist at the $\mu$-opioid receptor, in patients WITH moderate to severe acute pain requiring parenteral opioid therapy. J Pain Res. 2019;12:3113-26.

30. Overdyk FJ, Carter R, Maddox RR, Callura J, Herrin AE, Henriquez C. Continuous oximetry/capnometry monitoring reveals frequent desaturation and bradypnea during patient-controlled analgesia. Anesth Analg. 2007;105(2):412-8. 
31. Taylor S, Kirton OC, Staff I, Kozol RA. Postoperative day one: a high-risk period for respiratory events. Am J Surg. 2005;190(5):752-6.

32. Weingarten TN, Chong EY, Schroeder DR, Sprung J. Predictors and outcomes following naloxone administration during phase I anesthesia recovery. J Anesth. 2016;30(1):116-22.

33. Falzone E, Hoffmann C, Keita H. Postoperative analgesia in elderly patients. Drugs Aging. 2013;30(2):81-90.

34. Romero-Corral A, Caples SM, Lopez-Jimenez F, Somers VK. Interactions between obesity and obstructive sleep apnea: implications for treatment. Chest. 2010;137(3):711-9.

35. Cozowicz C, Chung F, Doufas AG, Nagappa M, Memtsoudis SG. Opioids for acute pain management in patients with obstructive sleep apnea: a systematic review. Anesth Analg. 2018;127(4): 988-1001.

36. Lee LA, Caplan RA, Stephens LS, Posner KL, Terman GW, Voepel-Lewis T, et al. Postoperative opioidinduced respiratory depression: a closed claims analysis. Anesthesiology. 2015;122(3):659-65.

37. Kharasch ED, Avram MJ, Clark JD. Rational perioperative opioid management in the era of the opioid crisis. Anesthesiology. 2020;132(4):603-5.

38. Kliewer A, Schmiedel F, Sianati S, Bailey A, Bateman JT, Levitt ES, et al. Phosphorylation-deficient G-protein-biased mu-opioid receptors improve analgesia and diminish tolerance but worsen opioid side effects. Nat Commun. 2019;10(1):367.

39. Viscusi ER, Skobieranda F, Soergel DG, Cook E, Burt DA, Singla N. APOLLO-1: a randomized placebo and active-controlled phase III study investigating oliceridine (TRV130), a G protein-biased ligand at the micro-opioid receptor, for management of moderate-to-severe acute pain following bunionectomy. J Pain Res. 2019;12:927-43.

40. Singla NK, Skobieranda F, Soergel DG, Salamea M, Burt DA, Demitrack MA, et al. APOLLO-2: a randomized, placebo and active-controlled phase III study investigating oliceridine (TRV130), a G protein-biased ligand at the mu-opioid receptor, for management of moderate to severe acute pain following abdominoplasty. Pain Pract. 2019;19(7): 715-31.

41. Dahan A, van Dam CJ, Niesters $M$, van Velzen $M$, Fossler MJ, Demitrack MA, et al. Benefit and risk evaluation of biased $\mu$-receptor agonist oliceridine versus morphine. Anesthesiol J Am Soc Anesthesiol. 2020;133(3):559-68.

42. Gan TJ, Wase L. Oliceridine, a G protein-selective ligand at the $\mu$-opioid receptor, for the management of moderate to severe acute pain. Drugs Today (Barc). 2020;56(4):269-86.

43. Jungquist CR, Quinlann-Colwell A, Vallerand A, Carlisle HL, Cooney M, Dempsey SJ, et al. American Society for Pain Management nursing guidelines on monitoring for opioid-induced advancing sedation and respiratory depression: revisions. J Pain Manag Nurs. 2020;21(1):7-25.

44. Griffin CE 3rd, Kaye AM, Bueno FR, Kaye AD. Benzodiazepine pharmacology and central nervous system-mediated effects. Ochsner J. 2013;13(2): 214-23.

45. Schmidt PC, Ruchelli G, Mackey SC, Carroll IR. Perioperative gabapentinoids: choice of agent, dose, timing, and effects on chronic postsurgical pain. Anesthesiology. 2013;119(5):1215-21.

46. Cavalcante AN, Sprung J, Schroeder DR, Weingarten TN. Multimodal analgesic therapy with gabapentin and its association with postoperative respiratory depression. Anesth Analg. 2017;125(1): 141-6.

47. Weingarten TN, Jacob AK, Njathi CW, Wilson GA, Sprung J. Multimodal analgesic protocol and postanesthesia respiratory depression during phase I recovery after total joint arthroplasty. Reg Anesth Pain Med. 2015;40(4):330-6.

48. Boitor M, Ballard A, Emed J, Le May S, Gélinas C. Risk factors for severe opioid-induced respiratory depression in hospitalized adults: a case-control study. Can J Pain. 2020;4(1):103-10. 